\title{
A Critique of the Question of African Philosophy
}

\author{
Omotosho I. F \\ Dept, of General Studies, Federal Polytechnic, Ede, Osun State, Nigeria.
}

\begin{abstract}
The history of African philosophy as a distinct academic discipline has witnessed a lot of controversies, debates, arguments and counter-arguments bordering on the issue of the existence or non existence of the discipline. This debate has been described by an erudite scholar, Makinde, as unnecessary. According to him, if African philosophy exists, then do it, teach it and write it instead of engaging in endless debate on its ontology. The focus of this paper is to examine his arguments in support of his (Mankinde's) claim that there is African philosophy. This is to show how his arguments authenticate African philosophy as a "specie" of philosophy thereby putting an end to this controversy. This is because, an end to this controversy, will move African philosophy forward to contribute to human, social and political development through its ethics, social and political philosophy, to mention a few.
\end{abstract}

\section{Introduction}

One of the important topics of debate in the past few decades has been on the ontology of African philosophy. The debate centers on whether African beliefs, worldviews and thoughts on the existence of god, immortality of the soul, destiny and so on can be called philosophy. Thus, the nature of African philosophy is not divulged from its existence. There are some who argue that African philosophy exists as a specie of philosophy while some argue that there is nothing like an authentic African philosophy. This debate has been described as unnecessary by Makinde. This paper examines his arguments to show the weaknesses and strengths of his points under each section. The paper observes that Makinde's arguments seem to support his claim.

\section{Philosophy In General}

In his paper, "The question of African philosophy", Makinde defines philosophy as "attempts to arrive at reasoned answers to important questions",2. For him there are no definite answers to philosophical questions. As to whether philosophy is concerned with all important questions, Makinde's answer seems to imply that philosophy is concerned with non scientific questions. Examples of the important questions that philosophy is concerned with include what is matter? What is mind? Is the world composed of matter and mind? What is the purpose of living? Has the universe any purpose? Why something rather than nothing? What is an experience of God? Is there life after death? And so on.

So, for Makinde, it is the attempt to provide reasoned answers to questions like the above that constitute the discipline called philosophy ${ }^{3}$.

However, he was quick to remark that his definition of philosophy is an attempt to provide a working definition as there are different schools and philosophers. So, there is no single universally accepted definition of philosophy. In his words, "Thus philosophers are of different temperament and their approach to philosophical problems are not the same", ${ }^{\prime 4}$ Apart from the fact that philosophers do not agree on the definition of philosophy, they are yet to agree on the subject matter of philosophy and the issue to be considered as philosophical issues.

However, one thing is clear, philosophy is not logical or linguistic analysis as some philosophers like Wittgenstein will want us to belief. This is true of all other schools of philosophy such as idealism, pragmatism, empiricism, rationalism, which holds the view that their own individual view is adequate to the comprehension of reality. No single conception of reality of any of the schools is all embracing.

In my own opinion Makinde's attempt at first defining philosophy is meant to pave way to show that philosophy, by definition, encompasses African philosophical thought. This is because, the linguistic analytic school may want us to believe that African traditional thought is unphilosophical just as they claim that metaphysical and ethical thoughts are unphilosophical. Thus, Makinde was quick to tell us that the analytic school's views of philosophy is just one out of many views and their conception of the nature and subject matter of philosophy is personal to members of the school.

In line with this opinion of mine, he points out that some philosophers's conception of philosophy and nature of philosophy are similar to that of African traditional thought. In Makinde's words 'African traditional thought also hold positions quite similar to Plato's and some of those mentioned above", 5

Just as you have various philosophical views in western philosophy, there are similar philosophical views in African traditional thought. Thus, there are idealism, Empiricism, materialism, spiritualism, mysticism, 
skepticism, communalism or socialism, metaphysics, ethic, philosophies in Africa traditional thought. For instance in African idealist philosophy, we find ideas similar to that of Plato's.

To the Yorubas of Southern Nigeria our world like Plato's empirical world is a mere appearance. So, to some Yorubas of Nigeria heaven not hearth is our home. Heaven is the ideal world. Having established this, Makinde argues that if Plato's thought is philosophical then the African thought is philosophical. Why? Because "both exhibit some sort of visionary power which in the worlds of Waisman, is the one single aspect and the most essential feature of philosophy" 6 .

It may be argued that African philosophy is not philosophy because it is not logical or linguistic analysis or identified with empirical science, Makinde's reply to such critics is that if the criteria of knowing what constitutes philosophy is linguistic analysis, only two branches of philosophy would stand recognition logic and Epistemology. But that cannot be the criteria of delimiting philosophy because metaphysics and ethics are core areas of philosophy notwithstanding the attempt of linguistic philosophers to reject them. In fact, metaphysics with its speculations ushered in the era of philosophy. So, African worldview need not identify with linguistic rigor or analysis before it can claim to be philosophical.

As to whether African traditional thought need to be a scientific world view in order to be philosophical, Makinde submits that it need not be. This is because a world view is a wider concept than philosophy. So, we can have ethical, religious, philosophical, scientific, political world views and so on. A philosophical world view is different from a scientific world view and so African philosophy need not be a scientific world view. Thus, African traditional thought need not be scientific to be a philosophical world view. Unlike scientific world view, "the philosophical world view is above all the posing of questions. These questions arise not only from scientific research, but also from individual and socio historical experience ---.- ${ }^{77}$ Thus, the philosophical world view may or may not be scientific. So, the African traditional thought is a philosophical world view. It may be argued that some traditional thoughts, say that of Europe are better than the others. Makinde argues that "there is no a priori method of showing which philosophical worldview is better than the other" ${ }^{8}$.

It may be argued that African philosophy has no tradition as it lacks great figures whose philosophy could be studied. Makinde contends that the absence of known great figures in African philosophy does not mean that there is no African traditional thought. This is because not all philosophical thoughts are written, Socrates, Buddha, Confucius did not write. Their thoughts were communicated to us through other writers, if the thoughts of these thinkers were recognized as philosophical, what prevents similar thoughts by African thinkers as philosophical. On the identification of a thought with a thinker, it is obvious that there cannot be a thought without a thinker. It may be argued that Socrates could not be said to be an unknown philosopher since his thoughts were presented by Plato. What is clear however is that there is a reportage problem of how to separate Socrates original thoughts from that of Plato. The same problem is what the African traditional thought suffers, more so that there is the problem of the absence of writing facilities. So, these thoughts were passed down from generation to generation through rote until the advent or use of writing materials in Africa. However there is nothing that stops anyone from using thoughts or materials from unknown thinkers (African traditional thought) as a basis for philosophical enquiry just as Plato did to the thoughts of Socrates and the myths of Homer. Makinde then submits "if doing philosophy is not necessarily writing philosophy, then the absence of written works by great African figures on African philosophy--- is no proof that African philosophy was and is, non existent",

\section{History of African Philosophy}

Makinde divides the history of African philosophy into three phases:

Unwritten Philosophy and unknown philosophers;

For Makinde, this is the era in which African did and taught philosophy but did not write it. This was a period when important philosophical thoughts were kept in the memories of individual and passed from generation to generation by rote learning. It was not until the second half of the twentieth century that the thoughts of African people began to enter print coupled with the fact that the identities of the thinkers were unknown; this period could be described as uneventful. For these reason, these African thoughts were mistakenly considered by missionaries and Anthropologies as the collective thought of the people of Africa ethno philosophy.

Though there is no evidence as to when philosophy started in Africa yet in North Africa, there is evidence that philosophy was done and written between 570 BC and 430 AD. St Augustine, a native of Tagaste in North Africa born in $354 \mathrm{AD}$ was the first Africa who did and wrote philosophy. According to Makinde, African philosophy existed from time immemorial if we consider the fact that the doctrine of immortality and transmigration of the soul existed in many parts of Africa of which Yoruba, south western part of Nigeria is one. However, it was first put into writing by the first known African philosopher, St. Augustine.

It seems paradoxical to describe this period as unwritten philosophy and unknown philosophers because there was at least one known philosopher, St Augustine who wrote. There might be others whose record 
was lost. This is possible. So it seems a paradox to say that this period is a period of unwritten philosophy while there is one written philosophy and one known philosopher during this period.

However, the point Makinde tries to make is well noted at least he succeeds in telling us that philosophy existed before the coming of the European and that Africa has a philosophical world view of her own. Be that as it may, Makinde's point seems to have been made that there were traditional African thought before the coming of the colonial administrators and scholars, though the scholars were not able to sieve the philosophical from the non- philosophical in it. However, their field works now serve as sources or provide philosophers with material to work with.

\section{Second Phase: Reorientation in Philosophy and the colonial ethnographers and Ethno - philosophers}

If there are no traditional African thought the ethnographers wouldn't have anything to present to us as enthnophilosophy. Even though, the ethnographers could not distinguish the philosophical from nonphilosophical thought, yet their field work serve as material for modern philosophers. The scholars in this second phase, according to Makinde, include colonial scholars' mainly European missionaries, ethnologists and ethnographers and indigenous African scholars whose main aims or interests were in studying African thought through their traditional religious and cultures. These orientationalists identified philosophy with tradition religious and culture. Makinde argues that all the fundamental misconceptions about African philosophy could be traced to these scholars. This is because there are no indication fom their writings that these scholars were able to recognize the philosophical from the non philosophical contents of African thought not to talk of distinguishing them. Even some of these scholars (colonial) who describe what they were looking for as philosophy were not technically competent to distinguish between philosophical and non philosophical thought. Among these scholars were levy-brurl, Reverend Father Temples, Reverend Father Alexis Kagame, Janheiz Jahn, Robin Horton and the African Theologian, John Mbiti.

Makinde argues further that the colonial scholars had a hidden agenda - to show that Africa is incapable of second order thought. So any discovery of a philosophy which bears any resemblance to western philosophy would be a troublesome discovery to anthropologists and ethnologists of the evolutionary school, for colonial educationalists and a disturbing event particularly for those who were concerned with African education. This was so because it would mean that the mission of the colonial scholars to educate and to civilize based on the preconceived idea that the whole of African mind was like a tabularaza, would turn out to be a disappointing exercise. To achieve their aim that Africa could not engage in second order thought, wherever philosophy is discovered, it was turn into enthnophilosophy- philosophy of a group mind or collective thought of a people. These ethnographers and other scholars fail to recognize the philosophical content and implications in a people's way of thinking. Though we may not blame them because you have to be a philosopher to some degree before you can discover the philosophy of a person or people, according to Russell. However the efforts of these scholars revealed that there is African thought wherein both philosophical and non philosophical thought lies. Herein lies their contribution.

\section{The third phase: Critical Reorientation in Philosophy and the Contemporary African Philosophers}

This is a period when trained philosophers react against ethno- philosophers. The most important contribution of this era is the debate as to whether or not there is African philosophy. However, for Makinde, the debate does not amount to doing African philosophy. The best way to find out that there is African philosophy is to examine the contents of African traditional thought rather than arguing endlessly or whether or not there is African philosophy. This is because the debate will not bring African philosophy to existence unless the traditional thoughts have philosophical components.

One of the arguments of those who claim that there is no African philosophy is that it is not rigorous as western philosophy. For Makinde we cannot use the analytic philosophy to determine other philosophies as nonexistent because analytic is just one of the many philosophical traditions in the west otherwise a lot of the contents of western philosophy such as metaphysics, ethics and existentialism would be dismissed as non philosophy. Thus, African philosophy cannot be dismissed on the ground that it is not rigorous or analytic.

On the view of Horton that African traditional thought was not philosophical because it is not analytic, that philosophy must be an empirical science and that philosophy is nothing but logic and epistemology, Makinde differs. He took up Horton that one needs not to have studied logic to think logically even though logic is important $t^{10}$. One thing that is clear and common is that there is no anywhere in the world in which principles of logic are never employed consciously or unconsciously. So logic is universal and cannot be relativised. It is one of the conditions by which we distinguish a human being from lower animals and this is why language is an important part of logic and reasoning.

If we consider logic as universal then we cannot deny it in any thought system without denying its universality in thought. And if we consider it to be relative, we cannot deny it in the thought system of others 
because if we deny it in the thought of others, it is not at all relative. Thus he dismisses the anthropologist case of prelogicism against African thought as unfounded.

Having shown that African traditional thought is logical, Makinde argues further that it is unnecessary to debate on whether there is African philosophy or not. Instead he counsels the debaters to look into African traditional thoughts as there are some thoughts that are philosophical in African traditional thought. These set of Euro -African philosophers should investigate and rigorously debate on these thoughts. These philosophers are advised to look for thoughts that are similar in both the European and African traditional thoughts or on same philosophical subjects and debate. Such philosophical issues that concern people everywhere include, the existence of God, the meaning of life and death, human destiny, freedom and determinism, concept of a person being or non being to mention a few .

This period of critical reorientation is the period when the contemporary Africans reacted against the ethno philosophers and debate as to whether there is African philosophy or not. For Makinde, this debate is the most notable contribution to philosophy in Africa today. However he claims that the debate is an exercise in western philosophy.

It seems to me a paradox, for Makinde, to say a debate on the existence of African philosophy such as this does not amount to doing African philosophy. It seems paradoxical because he claims that it "is a right step in that it led to the recognition of the possibility of African philosophy" ${ }^{11}$, and claims further "...Engineered by this debate, I had examined some of the contents of African thought and found thoughts quite similar to those in western philosophy such as the existence of God, concept of a person..."12.

It seems doubtful that Makinde's claim that the debate on African philosophy could be classified as a debate on western philosophy. Truly the methods used might be analytic yet the content is as to whether African thought can be rightly classified as philosophical or not .If Makinde's debate in his paper, "The question of African philosophy"1 , which is being examined, (that there are African philosophical thoughts that could be compared to western philosophical thoughts) then the whole debate on African philosophy is an issue in African philosophy not western philosophy - whatever the method used since there is no method that can be called the philosophical method.

I quite agree with Makinde that the debate should not be endless and that the debate is important because it marks the beginning of Modern African philosophy. At least, it has led people such as Makinde, to look at the contents of African thoughts and sieve the philosophical from the non-philosophical and to argue rightly that there is African philosophy.

However, Makinde's claim that the categories of philosophers who have seen philosophical merit in African thought have not bothered themselves to join the debate on whether or not there is African philosophy is doubtful. This is because the objective of Makinde in his paper is to show that there is African philosophy. It should be noted that he took up Horton on the view that African philosophy must be science or linguistic analysis to be philosophy.

Makinde reveals that there is much of the traditional thought that can properly be called philosophy even in the modern cotemporary sense of the word ${ }^{13}$. Such thought include the ones that are quite similar to those in western philosophy such as the existence of God, concept of a person, the mind-body problem, human destiny, immortality of the soul, moral responsibility and punishment, human values and so on.

For Makinde, there is no need to start arguing with those who argue endlessly as to the existence of African philosophy. Instead materials with which to write it can be found in traditional thoughts of Africans which can be found in the works of indigenous writers. To do this properly is the task of the philosopher, according to Makinde. Another source is wise sayings and aphorisms. If the aphorisms of Confucius, Seneca, and Socrates have inspired philosophical ideas, there is no reason why the wise saying of our unknown philosophers cannot inspire philosophical ideas about political human relations and ways of life in Africa as in Europe. Though the thinkers may not be known in the case of Africa, it is the thought that inspired philosophical ideas that is important not the thinkers.

To those who claim that philosophy must be analytic, Makinde argues that they are arguing as if there is only one method in philosophy. Original philosophical thoughts need not be analysis. They could be speculations which pave way for philosophical discussions. We can also find materials in the writings of indigenous writers. The work of the philosopher is to sieve the philosophical from the non philosophical using any method of studying philosophy.

However, critical analyses, argumentations like any method may be applied later by professional philosophers. Thus rigorous or critical philosophy means nothing than critical analysis of the original thought and concepts of others -traditional, ancient, and modern. Traditional philosophical thoughts of African will now form the original thought to which critical analysis can be applied by African professional philosophers instead of engaging in endless debate. 
In fact there is nothing spectacular about analytic philosophy as some philosophers have even argued that it is not philosophy but a tool for logical analyses of science. Even though, the so called analytic philosophy has been of great value in the philosophy of science, it has contributed in no small measure to the negative view of philosophy as not been able to contribute to society. -A parasitic discipline. This can be seen in the application for sponsorships in projects, scholarship because it has caused the impression that the whole business of philosophy is to argue (engage in endless debates about "meaning-less" arguments.)

According to Makinde, a change is been awaited, a revolution that will make philosophy to be sensitive to the welfare of the people, make the improvement of mankind the central focus of philosophy. African philosophy is well situated for this revolution because most of the issues raised are of great concern to the society. Such issues include, issues of moral values, human life, and moral responsibly, punishment, issues in African social and political philosophy, African medicine and culture to mention a few.

Makinde derides the way some philosophers which he calls, "Euro-African philosophers" who were trained in the west endlessly debate the existence or non-existence of African philosophy. They think that philosophy must be rigorous or exact but fail to state what they mean by "rigorous", "exact", and "inexact". Apart from the fact that Makinde had shown earlier that this claim is baseless, he argued further that we do not require that Chinese, Indian e.t.c. Philosophies be analytic in order to be philosophy. He wondered why African philosophy should be different. He contended that it is the recognition of these other philosophies- Asia, India, and china that gave rise to the idea of comparative philosophy.

He also argue that the works of African writers and statesmen such as Awolowo, Nkruma, Julius Nyerere, Leopold sengor and others in the area of social and political philosophy, should not be seen as national ideologies as some westernised African philosophers see them. After all, Marxism is a national ideology and yet it is a philosophy, so the equivalent original work of these African writers and statesmen should be seen as philosophy. I subscribe to this view because what is good for the goose is good for the gander. And if there is African thinkers and writers whose original works are comparable to the original works of western philosophers, then who says there is no African philosophy and African philosophers.

\section{Who is an African Philosopher?}

On who really is an African philosopher, Makinde argues that the question of language cannot be ruled out due to the connection between written and spoken language to thought systems. An African trained in the west might claim he understands the language of his people than an American or Briton writing and teaching African philosophy. He may claim to have an advantage in the form of firsthand knowledge of African cultures and philosophy over his western counterpart to whom the "unspoken" and "unwritten" language of African philosophy is a foreign language. Makinde argues that the foreigner may be denied the title of African philosopher because the language and the thought that gave birth to African philosophy are foreign to him. This according to him is just a difference of kind not degree and there is no degree of African philosophers.

However, the writing and teaching of African philosophy are still done in foreign language unlike other continental philosophies. For Makinde, until African philosophy is thought and written in African language, African may be nothing, but African philosophy in western guise. So for Makinde an African philosopher is a person who transmits his African philosophy and original thought through his African language. Thus, as at now, nobody can be called an African philosopher.

However, if this is so his recommendation that Awolowo, Sengor, Nkuruma, Nyerere who wrote their original African thought and ideas in English, whom Makinde calls African philosophers, do not qualifies to wear this tag of African philosopher. This is because their national ideologies or African philosophies were not transmitted through their African languages.

In the opinion of this paper, the case of Africa is peculiar considering that Makinde's proposal seems impracticable due to the fact that Nigeria has more than 250 languages not to talk of the whole of Africa. The question is which language can be said to be African language as no tribe will want to be relegated. The concept Africa needs clarification. Does it refers to Origin, those who speak African languages, does it include those born in Africa whose parents are born outside Africa or whose parents are born in Africa? In the opinion of this author, whoever understands an African language and can teach, do and write African philosophy whether in the native language or foreign language should be recognized as an African philosopher.

\section{Conclusion}

This paper has examined makinde's claim that there is African Philosophy and the arguments adduced in support and found that the premises could be said to support the claim that there is African Philosophy.

\section{Notes}

1. Makinde, M. (2007), 'The question of African philosophy', in African philosophy: The demise of A controversy Ile-Ife: ObafemiAwolowo University press limited. Pp 23-59 
2. Makinde 2007; 23

3. Makinde 2007; 24

4. Makinde $2007 ; 24$

5. Makinde 2007; 26

6. Makinde 2007; 27

7. Makinde 2007; 28

8. Makinde $2007 ; 28$

9. Makinde 2007; 33

10. Makinde 2007; 36

11 Makinde 2007;41

12 Makinde 2007;41

13 Makinde 2007;45

\section{Bibliography}

[1]. Appiah, K.A. (1992) "The Myth of an African World” in Appiah, K.A. (ed.), In My Father's House: Africa in the Philosophy of Culture (New York: Oxford University Press)

[2]. Bolaji I. O (1992) : God and Yoruba belief London: long man ltd

[3]. Dain, Bruce R. (2002) A Hideous Monster of the Mind: American Race Theory in the Early Republic (New York: Google Books)

[4]. Eze, E.C. ed. (1997) Postcolonial African Philosophy: A Critical Reader (Oxford: Blackwell Publishers)

[5]. Gbadegesin. O (1998): "Indi duality, community and moral order" in The African philosophy reader; P.H Coetzee and APJ Roux eds. London, Routecdge.

[6]. Makinde, M. (2007), African philosophy: The demise of A controversy Ile-Ife: ObafemiAwolowo University press limited. 